\title{
The Impact of Autonomy on Women's Agency
}

\author{
El impacto de la autonomía en la Agencia de las Mujeres \\ Jeyle Ortiz-Rodríguez / jeyle.ortizrodriguez@mavs.uta.edu \\ Universidad Autónoma de Nuevo León, México \\ Vijayan K. Pillai / pillai@uta.edu \\ University of Texas at Arlington, USA \\ Manuel Ribeiro-Ferreira / manuel.ribeirofr@uanl.edu.mx \\ Universidad Autónoma de Nuevo León, México
}

\begin{abstract}
Kabeer's simple and illustrative definition of empowerment is "the expansion in people's ability to make strategic life choices in a context where this ability was previously denied to them" (Kabeer, 1999: 437). Women's empowerment, then, is conceptualized as an increase in agency over time. Little is it known about the importance of the effect of 'self directed motivations and desires' and autonomy on women's agency. The purpose of this paper is to analyze the relationships among women's autonomy and labor force participation along with their effects on women's agency in Nuevo Leon, Mexico. For this, we use the structural equation modeling approach. Our results reveal that women's autonomy and participation in the labor market positively influence their agency levels.
\end{abstract}

Key words: agency, autonomy, women's labor force participation, gender equality, wellbeing.

Resumen: De acuerdo con Kabeer (1999), es posible definir empoderamiento como la expansión de la habilidad de las personas para realizar elecciones estratégicas en su vida en un contexto en el cual esta habilidad fue previamente negada. De esta manera, el empoderamiento es conceptualizado como un incremento en el nivel de agencia a través del tiempo. Existe poca información sobre la importancia del efecto de las motivaciones autodirigidas y de los niveles de autonomía de las mujeres sobre su nivel de agencia. El objetivo de este artículo es analizar las relaciones entre la autonomía de las mujeres y su participación en el mercado de trabajo, así como sus efectos sobre la agencia de las mujeres en Nuevo León, México. Para lo anterior, se utilizan modelos de ecuaciones estructurales. Los resultados de este artículo revelan que la autonomía de las mujeres y su participación en el mercado de trabajo afectan positivamente sus niveles de agencia.

Palabras clave: agencia, autonomía, participación femenina en la fuerza de trabajo, igualdad de género, bienestar. 


\section{Introduction}

It is well known that development programs and projects in the developing world should actively include women in all spheres of public life (Rogers, 2005). The impetus for this demand stems from several demographic and social constraints on the achievement of the goals of the development agenda (Nwoye, 2013). On the demographic side, fertility has declined in most developing countries with the exception of a few very poor countries (Bongaarts and Casterline, 2013).

Consequently, populations tend to age alongside a shrinking labor force necessary to carry on the tasks of economic development (Demeny, 2012). This has led to deliberations on liberalizing migration policies to gain access to skilled laborers from demographic billionaires such as India and China (Gordon, 2013). A second approach has been to encourage women's participation in labor force (Molyneux, 1985). In many developing countries such as Mexico, women have responded to opportunities for work. The proportion of women in working age groups in Mexico participating in the labor force increased from $19.6 \%$ in 1990 to $33.3 \%$ in 2010 (INEGI, 2010).

Even if the increase in the proportion of women participating in the labor force is impressive, social, psychological, and cultural resistances to persistence of strong patriarchal norms and values in society, which prescribe and limit the role of women to domestic chores (Sen and Grown, 2013). This conflict between women's domestic and occupational roles have raised new fears about the economic and social consequences, threats to women's commitment and career development in the labor force (Korpi, Ferrarini and Englund, 2013). These issues have become the subject of empirical scrutiny in the current development of literature under the rubric of women's agency (Staudt and Jaquette, 2013). Women's agency is broadly defined as a set of skills and propensities women posses and actively utilize in their own terms in order to achieve goals and objectives that enhance their well-being (Kabeer, 1999).

The development and promotion of women's agency has become an important development goal in recent years in developing countries (Masika and Bailur, 2015). Very few social consequences are as desirable as improvement in women's agency. Not only does women's agency have several desirable outcomes for their well-being, but also for members of the family and the communities as well (Mosedale, 2005). Women's agency is associated with increases in years of education, postponement of marriage and small family size (Schuler and Rottach, 2011). 
Women's agency improves not only child welfare and inculcates socially desirable behaviors with lasting impact on their well being throughout their life course (Hobson and Lindholm, 1997). The design and formulation of social policies are likely to benefit from an examination of the proximate determinants of women's agency (Hassim, 1999). The purpose of this paper is to examine the effects of a few selected determinants on women's agency in Nuevo Leon, Mexico.

In most developing countries today, women suffer from lower social status than men in both private and public domains. For example, in both low and moderate countries, the enrolment rate for girls in secondary school was $35.0 \%$ in 2011, while that for boys was almost $6 \%$ higher. Women's labor force participation rates remain significantly lower than that of men in almost all the occupational sectors of developing economies.

Women compared to men spend five times more time on childcare. Women in many developing countries lack independent rights to own land, manage property and conduct business; denial of property rights, honor killing, dowry related subjugation, lack of legal protection and exploitation of underage girls characterize the life of women in most developing countries even today (Cohen, 2006). Women's low status is accompanied by several social structural factors and also a normative climate that justifies women's subjugation (Damián, 2011; Levine, 1990).

In countries such as Mexico, programs that have been launched to improve women's social status are a key to the success of social policies (Molyneux, 2006). However, the effectiveness of such programs remains widely speculated and debated in the absence of empirical research on women's agency in Mexico (Casique, 2001; Luccisano, 2004). Both journalistic and anecdotal evidences cast doubt on the effectiveness of the empowerment program's role in improving women's agency (Luccisano, 2004 and 2006). However, empirical studies on women's agency in Mexico are few and far between.

The paper is organized under three sections. This section continues with a review of recent literature on women's agency in developing countries and proposes a hypothetical model of women's agency in Mexico. The second section presents the data and the results from the test of the hypothesized correlates of women's agency. Finally, the last section discusses the social contexts that promote women's agency in Mexico. 


\section{Correlates of women's agency}

Amartya Sen's theories of capacity building provide a theoretical framework for investigating women's agency (Hennink et al., 2012). Sen (2000) proposes a broad conceptual framework linking women's labor force participation and agency based on concepts of capabilities, functionings, and freedom. These concepts have gained attention since the integration of women's concerns into the development agenda in 1970 (Howard-Hassmann, 2011). Sen (2000) suggests two types of background variables among others, structural and normative, that influence women's agency. The structural variables are related to social positions and the extent of power associated with such positions. Interventions that promote socio-economic mobility and those which redistribute power by reallocating various types of resources across social positions are expected to bring about conditions conducive to improvements in women's agency (Dipna and Sharma, 2013).

The normative variables reflect socio-cultural values, laws and women's rights, which moderate the distribution of power across social positions. These background factors influence women's agency through autonomy (Acharya et al., 2010). The extent of autonomy women enjoy is related to their perception of power necessary to achieve desired goals and objectives (Hadjigeorgiou et al., 2012).

Agency, on the other hand, is related to perceptions of possibilities for intensification as well as expansion of power to achieve desired goals and objectives (Mishra and Tripathi, 2011). While social structural modifications often call for institutional reforms necessary to improve social mobility, normative changes may be induced by targeted legal as well as value changes (Mosedale, 2014).

Both social structural and normative changes intended for improving women's autonomy are likely to advance women's agency (Boudet, Petesch and Turk, 2013). Within the domestic sphere, norms with regard to household division of labor influence the level of women's agency (Sobritchea, 1990). As men actively participate in the production of goods and services within the household, they are more likely to partner with women in improving the levels of women's agency (Acharya et al., 2010).

Several indicators are available to operationalize autonomy in empirical research. Casique (2001) used nine variables to create a scale that reflects different dimensions of autonomy among Mexican married women. These variables measure whether women ask permission to: go out alone, go out with their children, incur daily expenses, visit friends, visit relatives, work 
outside the home, study, use a birth control method and participate in community activities.

Bojorquez-Chapela, Salgado and Casique (2009), using a similar survey, assess Mexican women's autonomy in four dimensions: decisionmaking power (women's participation in everyday decisions), movement autonomy (whether women need someone's permission to engage in some activities), political autonomy (participation in collective activities) and economic autonomy (assets and economic resources). García (2003) operationalizes autonomy in Mexico in terms of six selected characteristics: women's participation in intra-household decision making, freedom of movement, access and control of economic resources, lack of domestic violence, attitudes in favor of gender equality and being free to choose a spouse and the number children.

The concept of agency is characterized as processes of change where people start becoming aware of their power, possibilities, and influences in different groups and environments. Agency is born out of a recognition of the collective nature of human interactions and unequal relationships (Abrams, 1999). It is a process through which choices are made and attitudes generate a structure that guides future actions and constitutes people's identity (Hasselberger, 2012).

As women's access to resources through labor force participation increases, women's agency is likely to increase. Labor force participation bears a close association with the concepts of autonomy and agency. Although extra-domestic work may increase access to economic resources, in the Mexican context, women's labor force participation decisions are embedded in traditional family organizations that are conflict-ridden and slow to change (Ariza, 2000, as cited in Ariza and De Oliveira, 2003).

Mexican culture is patriarchal (Rendón, 2008; Stern, 1998). Women are encouraged to stay at home and engage in domestic activities while men assume their roles as breadwinners. Lack of women's status both at home and in the public sphere has constrained efforts to enhance their well-being (Rendón, 2008). Labor force participation remains low; in 2010, only 32.3 percent of Mexican women in working age were employed, while married, cohabiting and widowed women had the lowest participation rate, 29.8, 30.5 , and 22.8 percent, respectively (INEGI, 2010).

On the other hand, the burden of household chores may constrain women's agency as time and material resources are diverted away toward fulfilling domestic roles (Goldin, 1990). In sum, the proposed correlates of women's agency are likely to include autonomy, labor force participation, and 
amount of household chores (Soni-Sinha, 2011; Rajasingham-Senanayake, 2004; Shaheed, 1999). See Figure 1. ${ }^{1}$

\section{Methodology}

We hypothesize that women's agency is influenced by labor force participation and autonomy level. Figure 1 presents the hypothesized model of women's agency. The degree of participation in labor force is directly influenced by the level of autonomy women enjoy at the household level. Levels of autonomy have both a direct and an indirect effect on women's agency through women's degree of labor force participation. Furthermore, higher levels of women's autonomy are associated with higher partner's level of involvement with household chores. Table 1 presents the variables used to measure each construct.

To measure autonomy we utilize variables such as number of children younger than 12 years of age in the household, years in the current marital status, years of education and age at first marriage. Agency is indicated by a number of variables related to the women's opinion about their roles at both intra-household and extra-household levels; a number of variables related to household chores measure the level of their partners' participation in domestic work.

In order to test each component of the hypothesized model presented in Figure 1 and to ensure that all the latent variables are reliable and valid, each construct was evaluated separately using confirmatory factor analysis (CFA). Thus, confirmatory factor analysis is used to develop the measurement model.

All the measurement models were obtained by maximizing the goodness of fit with the help of modification indexes within limits of theoretical justification to alter their independent error structures. Most of the models were obtained by correlating at least two measurement errors based on modification indexes. The structural equation model was used to assess the causality among latent factors.

\section{Data}

The data for this study come from the Survey for the Diagnosis of Families in Nuevo Leon, a state-level representative survey conducted by the School of Social Work and Human Development of the Autonomous University of Nuevo Leon in 2010. The purpose of the survey was to obtain information regarding family dynamic and its relationships with the environment.

1 The figure and tables are in the Annex at the end of this article (Editor's Note). 
The survey consists of 2,681 cases from the 51 municipalities in Nuevo Leon. The sampling was based on the results of the Second National Count of Population and Housing conducted by the National Institute of Statistics and Geography of Mexico (INEGI). The stratified random sampling method was used to collect state-level representative data. In this study we use a sub-set of 1,462 households with both husband and wife present at the time of this study. A number of variables suffer from missing data. For variables with more than ten cases missing, we addressed the problem with mean imputation.

Table 2 presents the distribution of the used variables for each construct. On average, women have 3.14 children, 9.07 years of education and their first union was at the age of 21 . Regarding the partners' involvement in household chores, in most cases they never participate in domestic tasks.

\section{Results}

Table 3 presents the estimates from the CFA models of the four latent factors. Although the squared multiple correlation value for a few indicators is less than 0.250 , the goodness of fit index (GFI) for the respective constructs suggests a high level of theoretical validity for each of the four constructs with all the respective factor loadings significant at 0.01 level.

Table 4 presents the results from the estimation of the structural equation model for both models. Increases in women's autonomy lead to higher levels of agency. As women's autonomy increases by one unit, women's agency level increased by about 55.7 units. The levels of women's participation in labor market were positively related to women's agency; this suggests that when women's capabilities increase, they are more likely to seek the fulfillment of their desires and to guide the course of their lives from their own point of view and interests.

But the transformation of autonomy into agency is influenced by specific social structural characteristics and normative values that dictate women's and men's roles. Men's involvement in household chores was assumed to be correlated with women's autonomy. As expected, the correlation between household chores and autonomy is both positive and significant. Our results also suggest that women's participation in the labor market and women's level of autonomy positively influence agency. The effect of autonomy on agency measured in terms of the path coefficient is about two times the path coefficient between labor force participation and agency. 


\section{Conclusions and discussion}

Women's agency on matters that influence their well-being is of central concern for the provision of social as well as healthcare services (Molyneux, 1985). The purpose of this study was to assess the relationships among labor force participation, level of autonomy and women's agency. The effective exercise of women's capabilities implies the existence of freedom to pursue their desires and to choose among different available opportunities (Sen, 2000).

The significance of the relationship between agency and women's wellbeing in developing countries such as Mexico has not been adequately investigated (Casique, 2004; Wainerman, 2003). The impact of agency does not occur in a social vacuum (Charrad, 2010). Thus, even when women possess the skills and abilities to bring about change, theses resources do not necessarily influence their well-being. In this regard, our study highlights the importance of agency for women's well-being.

Even though the existing literature on women's well-being underscores the importance of the direct effect of autonomy, this study focused also on the neglected indirect effect of autonomy on agency mediated by women's participation in the labor force. We found the indirect effect of autonomy on agency to be significant. In this regard, our study suggests that the development of agency is crucial to the success of projects and programs. The success of many public programs such as family planning or poverty depends upon women's agency.

In general, our study finds that improvements in the development of agency can be achieved through different channels: promoting men's involvement in housework, improving autonomy, and increasing women's participation in the labor market. Since the latent factor 'autonomy' was indicated by measures such as number of years of education and number of children, improvements in these are likely to increase women's agency. Improvement in education not only enhances women's role inside and outside the household, but also improves access to better job conditions. We found the independent effect of labor force participation on women's agency to be significant and positive. At the policy level, this suggests that programs on women's agency should be pursued alongside programs and policies to improve labor force participation.

Women's entry into the labor market can be seen as an emancipating phenomenon that promotes equality between men and women both inside and outside the household. Through remunerated employment women are 
exposed to new interactions that redefine their roles (Baca, 2005; Goldin, 1990). Their participation in the labor force can modify their traditional practices as housewives and blur social aspects that confine them to the domestic sphere (Colón, 2010). The factor 'household chores' was used as a control in our model.

A challenge for future research is to assess the translation of women's agency into intended outcomes given their levels of autonomy, domestic chores workload, and participation in the labor market. Women are increasingly likely to be burdened with housework as their domestic workload does not decrease when they work outside the household (Del Tronco, 2008). Increases in men's involvement in the domestic sphere are likely to improve extra-domestic opportunities for women reinforcing their levels of autonomy and agency. Men's involvement in domestic tasks creates a social environment conducive to improvements in women's agency.

\section{References}

Abrams, Kathryn (1999), "From Autonomy to Agency: Feminist Perspectives on SelfDirection", in William \& Mary Law Review, year 40, no. 3, United States: College of William and Mary.

Acharya, Dev R. et al. (2010), "Research Women's autonomy in household decisionmaking: a demographic study in Nepal", in Reproductive Health, year 7, no. 15, England: Springer Natura.

Ariza, Marina and De Oliveira, Orlandina (2003), "Acerca de las familias y los hogares: estructura y dinámica”, in Catalina Wainerman [comp.], Familia, trabajo y género. Un mundo de nuevas relaciones, Argentina: Fondo de Cultura Económica de Argentina.

Baca, Norma (2005), "Ciudad, relaciones de género y trabajo extradoméstico", in Gaceta Laboral, year 11, no. 3, Brasil: Universidad del Zuila.

Bojorquez-Chapela, Ietza, Salgado, Nelly and Casique, Irene (2009), "International Migration of Partner, Autonomy and Depressive Symptoms among Women from a Mexican Rural Area", in International Journal of Social Psychiatry, year 55, no. 4, Inglaterra: Sage Journals.

Bongaarts, John and Casterline, John (2013), "Fertility Transition: Is subSaharan Africa Different?", in Population and Development Review, year 38, no. 1, United States: Population Council.

Boudet, Ana María, Petesch, Patti and Turk, Carolyne (2013), On Norms and Agency: Conversations about Gender Equality with Women and Men in 20 Countries, United States: World Bank Publications.

Casique, Irene (2001), "Abordando un proceso endógeno: la relación entre el trabajo extradoméstico femenino y el poder y autonomía de las mujeres casadas dentro del hogar en México", in Notas de población, year 28, no. 72, Chile: CEPAL.

Casique, Irene (2004), Poder y Autonomía de la Mujer Mexicana. Análisis de algunos condicionantes, México: Centro Regional de Investigaciones Multidisciplinarias. 
Charrad, Munira M. (2010), “Women's Agency Across Cultures: Conceptualizing Strengths and Boundaries", in Women's Studies International Forum, year 33, no. 6, Holland: Elsevier.

Cohen, Michelle Fram (2006), "The condition of women in developing countries", in The Independent Review, year 11, no. 2, United States: The Independent Institute.

Colón, Alice (2010), "Women's employment ans changing relationships in Puerto Rico", in Caribean Studies, year 38, no. 2, Puerto Rico: Universidad de Puerto Rico at Río Piedras.

Damián, Araceli (2011), "Pobreza y derechos socioeconómicos en México. Una mirada desde la perspectiva de género", in Tepichin, Ana María [comp.], Género y pobreza, México: Colegio de México.

Demeny, Paul (2012), "Geopolitical Aspects of Population in the Twenty First Century", in Population and Development Review, year 38, no. 4, United States: Population Council.

Del Tronco, José (2008), ¿Políticas pro-género o sesgo sexista de la política social?, in Zaremberg, Gisela [comp.], Politicas sociales y género, México: Flacso Mexico.

Dipna and Sharma, Puja (2013), "Women Empowerment as a Means of Inclusive Growth", in Journal of Business Management \& Social Sciences Research, year 2, no. 4, United Kingdom: Blue Ocean Research Journals.

García, Brígida (2003), "Empoderamiento y Autonomía de las Mujeres en la Investigación Demográfica Actual”, in Estudios Demográficos y Urbanos, year 18, no. 2, México: Colegio de México.

Goldin, Claudia (1990), Understanding the gender gap, United States: Oxford University Press.

Gordon, Edward (2013), Future Jobs: Solving the Employment and Skills Crisis: Solving the Employment and Skills Crisis, United States: ABC-CLIO.

Hadjigeorgiou, Eleni et al. (2012), "Women's perceptions of their right to choose the place of childbirth: an integrative review", in Midwifery, year 28, no. 3, Holland: Elsevier.

Hasselberger, William (2012), "Agency, Autonomy, and Social Intelligibility", in Pacific Philosophical Quarterly, year 93, no. 2, United States: University of Southern California.

Hassim, Shireen (1999), "From presence to power: women's citizenship in a new democracy", in Agenda, year 15, no. 40, United States: Taylor \& Francis Online.

Hennink, Monique et al. (2012), "Defining empowerment: perspectives from international development organisations", in Development in Practice, year 22, no. 2, United States: Taylor \& Francis Online.

Hobson, Barbara and Lindholm, Marika (1997), "Collective identities, women's power resources, and the making of welfare states", in Theory and Society, year 26, no. 4, United States: Springer Publishing.

Howard-Hassmann, Rhoda E. (2011), “Universal Women's Rights Since 1970: The Centrality of Autonomy and Agency", in Journal of Human Rights, year 10, no. 4, United States: Taylor \& Francis Online.

INEGI (2010), Censo General de Población y Vivienda, México: Instituto Nacional de Estadística, Geografía e Informática.

Kabeer, Naila (1999), "Resources, Agency, Achievements: Reflections on the Measurement of Women's Empowerment”, in Development and Change, year 30, no. 3, United States: Wiley Online Library. 
Korpi, Walter, Ferrarini, Tommy and Englund, Stefan (2013), “Women's opportunities under different family policy constellations: gender, class, and inequality tradeoffs in western countries re-examined", in Social Politics: International Studies in Gender, State \& Society, year 20, no. 1, England: Oxford Journals.

Levine, Ruth Ellen (1990), “Determinants of women's employment in metropolotan Mexico: a life cycle perspective”, Ph.D. Dissertation. United Kingdom:The Johns Hopkins University.

Luccisano, Lucy (2006), “The Mexican Oportunidades Program: Questioning the linking of security to conditional social investments for mothers and children", in Canadian Journal of Latin American and Caribbean Studies, year 31, no. 62, United States: Taylor \& Francis Online.

Luccisano, Lucy (2004), “Mexico's Progresa Program: An example of neo-liberal poverty alleviation programs concerned with gender, human capital development, responsibility and choice", in Journal of Poverty, year 8, no. 4, United States: Taylor \& Francis Online.

Masika, Rachel and Bailur, Carol (2015), "Negotiating Women's Agency through ICTs A Comparative Study of Uganda and India", in Gender, Technology and Development, year 19, no. 1, England: Sage Journals.

Mishra, Nripenddra K. and Tripathi, Tulika (2011), "Conceptualising Women's Agency, Autonomy and Empowerment”, in Economic and Political Weekly, year 44, no. 11, Mumbai: Sameeksha Trust.

Molyneux, Maxine (2006), "Mothers at the service of the new poverty agenda: Progresa/ Oportunidades, Mexico's conditional transfer programme”, in Social Policy and Administration, year 40, no. 4, United States: Wiley Online Library.

Molyneux, Maxine (1985), "Mobilization without emancipation? Women's interests, the state, and revolution in Nicaragua", in Feminist Studies, year 11, no. 2, United States: Feminist Studies.

Mosedale, Sarah (2005), “Assessing women's empowerment: towards a conceptual framework", in Journal of International Development, year 17, no. 2, United States: Wiley Online Library.

Mosedale, Sarah (2014), “Women's empowerment as a development goal: taking a feminist standpoint”, in Journal of International Development, year 26, no. 8, United States: Wiley Online Library.

Nwoye, May (2013), "Gender responsive entrepreneurial economy of Nigeria: Enabling women in a disabling environment", in Journal of International Women's Studies, year 9, no. 1, United States: Bridgewater State University.

Rajasingham-Senanayake, Darini (2004), "Between Reality and Representation Women's Agency in War and Post-Conflict Sri Lanka”, in Cultural Dynamics, year 16, no. 2-3, England: Sage Journals.

Rendón, Teresa (2008), Trabajo de hombres y trabajo de mujeres en el siglo XX, México: Universidad Nacional Autónoma de México.

Rogers, Barbara (2005), The domestication of women: Discrimination in developing societies, England: Routledge.

Schuler, Sidney Ruth and Rottach, Elisabeth (2011), "Why Does Women's Empowerment In One Generation Not Lead To Later Marriage and Childbearing In The Next?: Qualitative Findings from Bangladesh", in Journal of Comparative Family Studies, year 42, no. 2, Canada: University of Calgary. 
Sen, Amartya (2000), Desarrollo y Libertad, España: Planeta.

Sen, Gita and Grown, Caren (2013), Development crises and alternative visions: Third world women's perspectives, England: Routledge.

Shaheed, Farida (1999), “Constructing identities: Culture, women's agency and the Muslim World”, in International Social Science Journal, year 51, no. 159, United States: Wiley Online Library.

Sobritchea, Carolyn Israel (1990), “The ideology of female domesticity: its impact on the status of Filipino women”, in Review of Women's Studies, year 1, no. 1, Philippines: University of Philippines.

Soni-Sinha, Urvashi (2011), "Invisible women: a study of jewelry production in West Bengal, India”, in Journal of Gender Studies, year 20, no. 2, United States: Taylor \& Francis Online.

Staudt, Kathleen and Jaquette, Jane S. (2013), Women in developing countries: A Policy focus, England: Routledge.

Stern, Steve J. (1998), "What Comes After Patriarchy? Reflections from Mexico”, in Radical History Review, year 71, England: Duke University Press.

Wainerman, Catalina (2003), "La reestructuración de las fronteras de género", in Wainerman, Catalina [comp.], Familia, trabajo y género. Un mundo de nuevas relaciones, Argentina: Fondo de Cultura Económica de Argentina.

\section{Annex}

Figure 1

\section{Hypothesized models of women's agency}

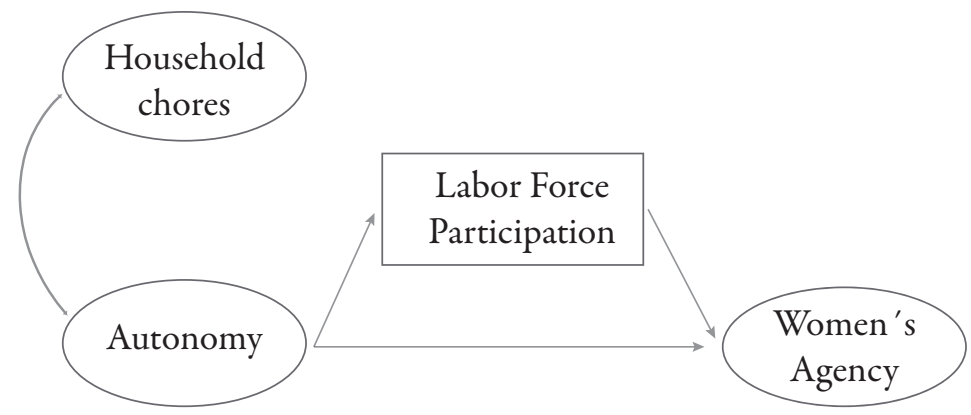

Source: own elaboration. 


\section{Table 1}

\section{Description of variables and constructs}

\begin{tabular}{|c|c|c|c|}
\hline Construct & $\begin{array}{l}\text { Observed } \\
\text { Variables }\end{array}$ & Description & \\
\hline \multirow{4}{*}{ Autonomy } & v27 & \multicolumn{2}{|l|}{ Number of children $<12$ years old } \\
\hline & v71 & \multicolumn{2}{|l|}{$(\text { Years of current marital status })^{*}(-1)$} \\
\hline & education & \multicolumn{2}{|l|}{ Years of education. } \\
\hline & v68 & \multicolumn{2}{|l|}{ Age at first marriage or first union. } \\
\hline \multirow{5}{*}{$\begin{array}{l}\text { Household } \\
\text { chores }\end{array}$} & v101 & How often does your couple cook? & \multirow{5}{*}{$\begin{array}{l}11 \text { never } \\
12 \text { rarely } \\
13 \text { frequent } \\
14 \text { daily }\end{array}$} \\
\hline & v102 & How often does your couple do the dishes? & \\
\hline & v103 & How often does your couple do the laundry? & \\
\hline & v104 & How often does your couple clean up the house? & \\
\hline & $\mathrm{v} 105$ & $\begin{array}{l}\text { How often does your couple clean up the yard or } \\
\text { the front of the house? }\end{array}$ & \\
\hline \multirow[t]{11}{*}{$\begin{array}{l}\text { Women's } \\
\text { agency }\end{array}$} & v127 & $\begin{array}{l}\text { Married women should stay at home instead of } \\
\text { working. }\end{array}$ & \multirow{11}{*}{$\begin{array}{l}11 \text { agree } \\
12 \text { neither } \\
\text { agree or } \\
\text { disagree } \\
13 \text { disagree }\end{array}$} \\
\hline & v129 & $\begin{array}{l}\text { If the husband earns enough money, his wife } \\
\text { should not work out of the household. }\end{array}$ & \\
\hline & v130 & Women have to do the housework. & \\
\hline & v131 & $\begin{array}{l}\text { Your husband is who has to dictate what goes on } \\
\text { in the household. }\end{array}$ & \\
\hline & v132 & $\begin{array}{l}\text { If women have no economic needs, they should } \\
\text { not work outside the household. }\end{array}$ & \\
\hline & $\mathrm{v} 135$ & $\begin{array}{l}\text { If women have young children, they should not } \\
\text { work outside the household. }\end{array}$ & \\
\hline & v137 & $\begin{array}{l}\text { Women should follow their husband wherever he } \\
\text { goes, even if they do not like it. }\end{array}$ & \\
\hline & v139 & $\begin{array}{l}\text { Women that stay all day at their household are } \\
\text { better mothers than those that work outside the } \\
\text { household. }\end{array}$ & \\
\hline & v147 & $\begin{array}{l}\text { When men let women work, they are taking the } \\
\text { risk at being cheated. }\end{array}$ & \\
\hline & v151 & Men have the right to forbid women to work. & \\
\hline & v159 & $\begin{array}{l}\text { If married women want to work, they need their } \\
\text { husband's permission. }\end{array}$ & \\
\hline $\begin{array}{l}\text { Women's } \\
\text { participation in } \\
\text { labor market }\end{array}$ & $\mathrm{v} 82$ & Natural logarithm of weekly working hours. & \\
\hline
\end{tabular}

Source: Survey for the Diagnosis of Families in Nuevo Leon 2010. 


\section{Table 2}

\section{Descriptive Statistics of Variables}

\begin{tabular}{|c|c|c|c|c|c|}
\hline Construct & Variable & Daily & Frequently & Rarely & Never \\
\hline \multirow{6}{*}{$\begin{array}{l}\text { Household } \\
\text { chores }\end{array}$} & v101 & 7.6 & 16 & 31.8 & 44.6 \\
\hline & v102 & 5.7 & 13.1 & 24.5 & 56.6 \\
\hline & v103 & 2.9 & 8.4 & 16.1 & 72.6 \\
\hline & v104 & 4.9 & 16.1 & 26.1 & 53 \\
\hline & v105 & 6.8 & 20.2 & 25.1 & 47.9 \\
\hline & & Agree & $\begin{array}{l}\text { Neither agree } \\
\text { nor disagree }\end{array}$ & Disagree & \\
\hline \multirow{12}{*}{$\begin{array}{l}\text { Women's } \\
\text { agency }\end{array}$} & v127 & 28.1 & 7.5 & 64.4 & \\
\hline & v129 & 52.2 & 5.3 & 42.6 & \\
\hline & v130 & 27.5 & 4.4 & 68.1 & \\
\hline & v131 & 22.2 & 5.5 & 72.3 & \\
\hline & v132 & 50.2 & 5.4 & 44.4 & \\
\hline & v135 & 56.2 & 8.1 & 35.7 & \\
\hline & v137 & 33.5 & 5.8 & 60.7 & \\
\hline & v139 & 27 & 8 & 65 & \\
\hline & v147 & 19.4 & 10.2 & 70.4 & \\
\hline & $\mathrm{v} 151$ & 26.9 & 6.4 & 66.7 & \\
\hline & v159 & 55.3 & 8.5 & 36.2 & \\
\hline & & Mean & $\begin{array}{l}\text { Standard } \\
\text { Deviation }\end{array}$ & Mode & \\
\hline \multirow{5}{*}{ Autonomy } & children $<12$ & 0.81 & 1.01 & 0 & \\
\hline & children & 3.14 & 1.99 & 3 & \\
\hline & v71 & 21.88 & 13.64 & 20 & \\
\hline & education & 9.07 & 4.12 & 9 & \\
\hline & $\mathrm{v} 68$ & 21 & 4.78 & 18 & \\
\hline $\begin{array}{l}\text { Women's } \\
\text { participation in } \\
\text { labor market }\end{array}$ & v82 & 9.2 & 18.22 & 0 & \\
\hline
\end{tabular}

Source: Own estimates with information from the Survey for the Diagnosis of Families in Nuevo Leon 2010. 


\section{Table 3}

Loading factors, squared multiple correlation value and goodness of fit of the measurement model

\begin{tabular}{|c|c|c|c|c|}
\hline Construct & Observed Variable & Factor Loading & $\mathrm{R} 2$ & GFI \\
\hline \multirow{4}{*}{ Autonomy } & V27 & 1.000 & 0.445 & 0.999 \\
\hline & v71 & 47.693 & 0.985 & \\
\hline & education & 5.340 & 0.131 & \\
\hline & $\mathrm{v} 68$ & 2.150 & 0.016 & \\
\hline \multirow{5}{*}{$\begin{array}{l}\text { Household } \\
\text { chores }\end{array}$} & v101 & 1.000 & 0.483 & 0.995 \\
\hline & v102 & 1.088 & 0.625 & \\
\hline & v103 & 0.717 & 0.439 & \\
\hline & v104 & 1.009 & 0.720 & \\
\hline & v105 & 0.951 & 0.560 & \\
\hline \multirow{11}{*}{$\begin{array}{l}\text { Women's } \\
\text { agency }\end{array}$} & v127 & 1.000 & 0.270 & 0.957 \\
\hline & v129 & 1.041 & 0.380 & \\
\hline & v130 & 1.123 & 0.179 & \\
\hline & v131 & 0.874 & 0.349 & \\
\hline & v132 & 1.042 & 0.188 & \\
\hline & v135 & 0.803 & 0.185 & \\
\hline & v137 & 0.798 & 0.292 & \\
\hline & v139 & 1.029 & 0.280 & \\
\hline & v147 & 0.677 & 0.406 & \\
\hline & v151 & 1.081 & 0.293 & \\
\hline & v159 & 0.975 & 0.319 & \\
\hline
\end{tabular}

Source: Own estimates with information from the Survey for the Diagnosis of Families in Nuevo Leon 2010.

Note: All estimates are significant at a 0.01 level. 
Table 4

Coefficients and goodness of fit of the Structural Equation Model

\begin{tabular}{llllll}
\hline & $\begin{array}{c}\text { Coefficients } \\
\text { and } \\
\text { covariances }\end{array}$ & GFI & AGFI & CFI & RMSEA \\
\hline $\begin{array}{l}\text { Autonomy => Agency } \\
\text { Participation in the L.M. => }\end{array}$ & 0.557 & 0.951 & 0.938 & 0.934 & 0.047 \\
$\begin{array}{l}\text { Agency } \\
\begin{array}{l}\text { Autonomy => Participation in } \\
\text { L. M. }\end{array}\end{array}$ & 0.340 & & & & \\
$\begin{array}{l}\text { Household Chores }<=> \\
\text { Participation in L.M. }\end{array}$ & 0.046 & & & & \\
\hline
\end{tabular}

Source: Own estimates with information from the Survey for the Diagnosis of Families in Nuevo Leon 2010.

Notes: All estimates are significant at a 0.01 level; $<=>$ stands for covariance and $=>$ coefficient.

Jeyle Ortiz Rodríguez. Ph.D. in Social Policy and Social Work from the University of Texas at Arlington. She received her bachelor's degree in Economics from Universidad Autónoma de Nuevo León (UANL) and her master's degree in Economics and Public Policy from Escuela de Graduados de Administración Pública y Politica Pública. She is a Professor at the School of Business at UANL. Her research interests are gender and social wellbeing. Recent work: Child Malnutrition and Gender Preference in India: The Role of Culture", in Health Science Journal, year 9, no. 6, Monterrey: Universidad Autónoma de Nuevo León (2015); "Efecto de la condicionalidad del programa Oportunidades sobre la distribución del tiempo de los integrantes de los hogares beneficiados", in Trayectorias Revista de Ciencias Sociales, year 17, no. 40, Monterrey: Universidad Autónoma de Nuevo León (2015); "Developing a construct of women's sexual freedom in the Mexican context", in Social Indicators Research, vol. 127, no. 3, New York: Springer Publishing (2016). 
Vijayan K. Pillai. Professor at the School of Social Work at the University of Texas at Arlington. Ph.D. in Sociology from the University of Iowa. His research interests are international social work, reproductive health, and gender. Recent publications: "Reproductive Health and Social Development in Developing Countries: Changes and Inter-relationships", in British Journal of Social Work, Oxford: Orxford Journals (2013); "Assessing the participation of women in Micro-finance institutions-Evidence from a Multi-National Study", in Journal of Social Service Research, Abingdon: Taylor \& Francis Online (2013); and "Developing a construct of women's sexual freedom in the Mexican context", in Social Indicators Research, vol. 127, no. 3, New York: Springer Publishing (2016).

Manuel Ribeiro Ferreira. Professor at the School of Social Work at Universidad Autónoma de Nuevo León. He received his bachelor's degree in Sociology from Universidad Iberoamericana. His research interests are family and gender. He is a member of the National System of Researchers, level II. He received his Ph.D. from Laval University. Recent publications: "El proceso de envejecimiento y su impacto sociofamiliar", in Revista Latinoamericana de Estudios de Familia, Caldas: Universidad de Caldas (2012), and "El divorcio en Nuevo León: tendencias actuales", in Papeles de Población, Toluca: Universidad Autónoma del Estado de México (2014).

Reception: September $25^{\text {th }}, 2015$.

Approval: October $6^{\text {th }}, 2016$. 
